\title{
Microhabitat use and diet of Anotosaura vanzolinia (Squamata: Gymnophthalmidae) in a Caatinga area, Brazil
}

\author{
Bruno Halluan Soares de Oliveira ${ }^{1}$ \& André Luiz Machado Pessanha ${ }^{2,3}$ \\ ${ }^{1}$ Laboratório de Herpetologia, Departamento de Sistemática e Ecologia, \\ Universidade Federal da Paraiba - UFPB Campus I, Castelo Branco, \\ CEP 58051-900, João Pessoa, PB, Brasil \\ ${ }^{2}$ Departamento de Biologia, Universidade Estadual da Paraiba - UEPB, \\ Av. das Baraúnas, 151, Bairro Universitário, CEP 58429-500, Campina Grande, PB, Brasil \\ ${ }^{3}$ Corresponding author: André Luiz Machado Pessanha, e-mail: andrepessanhauepb@gmail.com
}

OLIVEIRA, B.H.S. \& PESSANHA, A.L.M. Microhabitat use and diet of Anotosaura vanzolinia (Squamata: Gymnophthalmidae) in a Caatinga area, Brazil. Biota Neotrop. 13(3): http://www.biotaneotropica.org.br/ v13n3/en/abstract?article+bn03913032013

\begin{abstract}
This study aimed to analyze the microhabitat use and diet of the lizard Gymnophthalmidae Anotosaura vanzolinia (Dixon 1974) in the Complexo Aluízio Campos ( $7^{\circ} 16^{\prime} 34^{\prime}$ S, 35 53' 7' W), an area of the Caatinga in the Campina Grande, Paraíba. We studied a total of 12 transects by active searching during the daytime. In each sample, habitat and microhabitat types occupied by the specimen were categorized, together with solar incidence and soil type. For all individuals, morphometric measurements were performed, as well as dissection for stomach content analysis. We collected a total of 46 individuals, with a snout-vent length ranging between 19 and $45 \mathrm{~mm}$, collected over all habitats, with prevalence in soil and earthy litter microhabitats near rocky outcrops. The dietary analysis showed a use of items of soil fauna and identified 14 types of prey, mainly insects such as termites and ants. It was observed that smaller individuals (SVL $<30 \mathrm{~mm}$ ) fed mainly on Hymenoptera (Family Formicidae), whereas larger individuals (SVL $>30 \mathrm{~mm}$ ) selected Isoptera.
\end{abstract}

Keywords: fossorial lizards, feeding ecology, gymnophthalmid lizard, foraging.

OLIVEIRA, B.H.S. \& PESSANHA, A.L.M. Uso do microhabitat e dieta de Anotosaura vanzolinia (Squamata: Gymnophthalmidae) em uma área de Caatinga, Brasil. Biota Neotrop. 13(3): http://www.biotaneotropica. org.br/v13n3/pt/abstract?article+bn03913032013

Resumo: O presente trabalho objetivou analisar o uso do microhabitat e a dieta do lagarto Gymnophthalmidae Anotosaura vanzolinia (Dixon 1974) no Complexo Aluízio Campos ( $7^{\circ} 16^{\prime} 34^{\prime}$ S, $35^{\circ}$ 53' 7' W), uma área de Caatinga do município de Campina Grande, Paraíba. Foram estudados ao todo 12 transectos utilizando a metodologia de busca ativa diurna. Em cada expedição foram categorizados os tipos de habitat e microhabitat ocupado pelo espécime, além de dados de incidência solar e tipagem do solo. Para os indivíduos coletados, foram tomadas medidas morfométricas além da dissecação para análise do conteúdo estomacal. Foi coletado um total de 46 indivíduos, com um comprimento rostro-cloacal variando entre 19 e $45 \mathrm{~mm}$, coletados ao longo de todos os habitats, com prevalência nos microhabitats com serrapilheira e solo terroso próximo a afloramentos rochosos. A análise da dieta evidenciou uma utilização de itens da fauna edáfica, sendo identificados 14 tipos de presas, principalmente insetos como cupins e formigas. Foi observado que indivíduos menores $(\mathrm{CRC}<30 \mathrm{~mm})$ alimentam-se principalmente de Hymenoptera (Família Formicidae) enquanto os indivíduos maiores (CRC > $30 \mathrm{~mm}$ ) selecionaram Isoptera.

Palavras-chave: lagartos fossoriais, ecologia alimentar, lagartos gimnoftalmídeos, forrageio. 


\section{Introduction}

The Gymnophthalmidae, informally referred to as microteiids, comprises about 178 species occurring in wide variety of habitats in Central and South America (Pelegrino et al. 2001). A characteristic of the species that make up the family is generally the reduction or atrophy of limbs, accompanied by corporal elongation (Novaese-Silva \& Araújo 2008, Kunz et al. 2011). Among the species of microteiids, Anotosaura vanzolinia Dixon, 1974, is a small lizard restricted to semiarid regions of northeastern Brazil (Rodrigues 2003). This semi-fossorial lizard occurs in mesic areas with abundant leaf litter and has not been registered in open areas or the more rustic Caatinga biome (Rodrigues 2003). Currently, information concerning microteiid distribution in this ecosystem, suggests that they can be found in patches of relictual forests, with deciduous broad-leaved trees that provide an accumulation of leaf litter (Rodrigues 1986, Gogliath et al. 2010). Delfim \& Freire (2007) also identify the absence of this specie in studies carried out in the Caatinga, possibly due to cryptic and fossorial habits. Further studies are necessary to clarify this issue and to identify possible distribution determinants of the species in this ecosystem.

The importance of habitats and microhabitats explored by lizards is directly related to opportunities for thermoregulation, feeding, reproduction and defense against predators, which might vary for each species (Novaes-e-Silva \& Araújo 2008). Being ectothermic, lizards preferentially choose habitats and microhabitats that facilitate thermoregulation, making use of environmental variables such as air temperature, substrate and direct solar radiation (Teixeira-Filho et al. 1995). However, the relative importance of each of these heat sources might vary interspecifically with the habitat in which the lizard is found (Vargens et al. 2008). The use of different microhabitats by Brazilian lizards has been described in the Amazon rainforest (Vitt et al. 2007), in Restingas (Menezes et al. 2006), in Atlantic forest (Maia et al. 2011) and also in the Caatinga (Arzabe et al. 2005, Dias \& Rocha 2007, Santana et al. 2011).

Factors that affect the diet of lizards include ontogenetic changes in prey preference, sex and foraging tactics (Vitt et al. 2003, Menezes et al. 2006). In addition, lizard diet composition might depend on the association they have with the microhabitat (Liou 2008). Vitt et al. (2008) even claim that evolutionary history plays an important role in determining differences in diet amongst lizards. Study of the diet not only generates information about the types of prey, but also data regarding foraging strategies performed by lizards, as well as the importance of prey in their diet (Cappellari et al. 2007, Kolodiuk 2008, Montechiaro 2008). Thus, the trophic relationships between lizards and their environment, together with the mode of foraging are some of the most important aspects of the ecology of these organisms (Rocha 1994). Given the current level of knowledge of the ecology of A. vanzolinia and its endemic condition, this research aimed to record the use of habitats and microhabitats by this microteiid, as well as their feeding habits in an ecosystem of the semiarid region of Brazil.

\section{Material and Methods}

The study area is located within the Complexo Aluízio Campos ( $7^{\circ} 16^{\prime} 34^{\prime \prime} \mathrm{S}$ and $\left.35^{\circ} 53^{\prime} 7^{\prime \prime} \mathrm{W}\right)$, in the Campina Grande municipality, Paraíba State, Brazil, at an altitude of approximately $550 \mathrm{~m}$ a.s.1. The climate is hot and humid with an annual mean temperature between $22{ }^{\circ} \mathrm{C}$ and $28{ }^{\circ} \mathrm{C}$ and a mean relative humidity of $75 \%$ to $83 \%$ (Rocha 2011). The habitat is covered by herbaceous and shrubby vegetation, with a large number of rocky outcrops where the most represented plant families are Bromeliaceae and Cactaceae (Alves et al. 2010).
For the study, 12 quadrants of $100 \mathrm{~m}^{2}$ were selected, which covered different types of vegetation and habitats. The lizards were caught during the dry season (March-April 2011) and the rainy season (July-August 2011) by an active diurnal search method (from 8.00 a.m. to 5.00 p.m.). At each site, rocks, timber, or other surface debris that might serve as lizard refuge sites, were lifted/rolled-over, in addition to making shallow excavations in the soil. To record the type of habitat and microhabitat where the specimens were found, we used the classification proposed by Delfim \& Freire (2007). The habitats included: sparse shrubby vegetation, dense shrubby vegetation, sparse arboreal vegetation, dense arboreal vegetation, sparse shrubby-arboreal vegetation and dense shrubby-arboreal vegetation. The microhabitat types were: leaf litter around shrubs, leaf litter among bromeliads, leaf litter around rocky outcrops and leaf litter isolated. Differences in microhabitat use were tested using the G test (Zar 1996).

After preservation in $10 \%$ formalin and storage in $70 \%$ alcohol, snout-vent length (SVL) was measured with a digital caliper to the nearest $0.1 \mathrm{~mm}$ and the specimens were deposited at the Laboratory of Zoology of the Universidade Estadual da Paraíba. The lizards were dissected and their gastrointestinal contents were analyzed qualitatively and quantitatively, including the frequency of occurrence (FO\%), numerical percentage ( $\mathrm{N} \%$ ), and the volumetric percentage $(\mathrm{V} \%)$. Food items were identified to the lowest possible taxonomic level. Subsequently, the Index of Relative Importance (IRI) was calculated, according to the formula $(\mathrm{N} \%+\mathrm{V} \%) \times \mathrm{FO} \%$ (Pinkas et al. 1971). The data for numerical abundance of food items were used to calculate the Shannon-Wiener diversity index, which was used as an indicator of niche breadth (Krebs 1989). Two morphologic groups based on body size were categorized: individuals with an $\mathrm{SVL}<30 \mathrm{~mm}$ and individuals with an SVL $>30 \mathrm{~mm}$.

\section{Results}

\section{Habitat and microhabitat}

Forty-six specimens of $A$. vanzolinia were recorded, with a SVL ranging from 19 to $45 \mathrm{~mm}$ (Figure 1). The specimens were captured in the leaf litter, which was moist and consisted of a large amount of decaying matter. Among the available habitats, the microteiids were captured mainly in sparse shrubby vegetation $(n=24,52.17 \%)$, dense shrubby vegetation ( $\mathrm{n}=7,15.22 \%)$ and dense shrubby-arboreal vegetation $(\mathrm{n}=7,15.22 \%)$ (Figure 2$)$. Analyzing the available

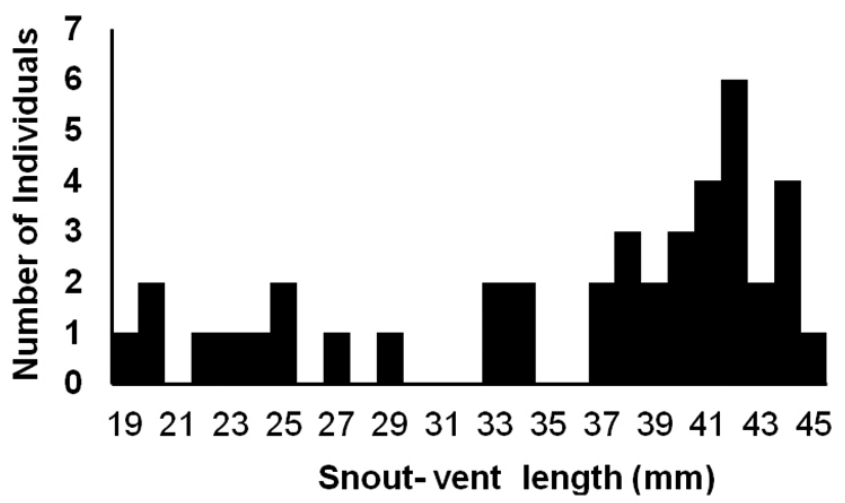

Figure 1. Histogram of the snout-vent length of Anotosaura vanzolinia captured in Complexo Aluízio Campos, Campina Grande, Paraíba State, Brazil. 
microhabitats, the specimens were captured mainly around rocky outcrops $(n=30,65.22 \%)$ (Figure 3$)$. In these microhabitats, the solar incidence ranged between in shaded $(n=13,28.26 \%)$, light filtered through the trees $(\mathrm{n}=28,60.87 \%)$ and sunny environments $(\mathrm{n}=5,10.87 \%)$. All specimens were collected on earthy soil and lizards were not recorded at sites with sandy or clayey soils. The G test showed a significant difference in the microhabitat occupied by A. vanzolinia $\left(\mathrm{G}_{3,0.05}=29.16\right)$.

\section{Diet}

The diet of $A$. vanzolinia consisted of 14 different prey types, represented by small arthropods (Arachnida, Crustacea, Hexapoda and Diplopoda) and Gastropoda; in the case of insects, were recorded six orders, beyond the eggs and larvae of these animals. From the total number of stomachs analyzed, only three $(6.81 \%)$ were found empty and Hymenoptera-Formicidae (44.74\%) and Isoptera $(39.47 \%)$ were the most frequent insects found (Table 1). The most numerically abundant items were eggs of invertebrates $(32.42 \%)$ and Isoptera $(28.33 \%)$, while volumetrically the main items were Isoptera (29.01\%) and Hymenoptera (17.75\%). The highest IRI values for items were for Isoptera (39.77\%), followed by HymenopteraFormicidae (29.24\%) and eggs of invertebrates (18.17\%) (Table 1).

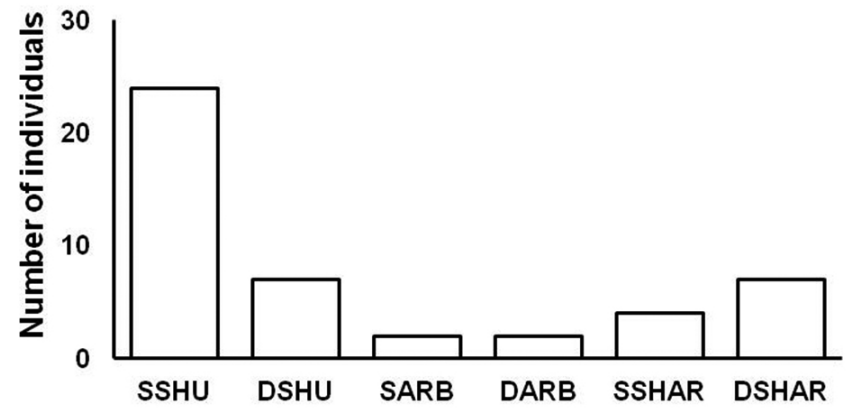

Figure 2. Number of individuals of Anotosaura vanzolinia by habitats at Complexo Aluízio Campos, Campina Grande, Paraíba State, Brazil, in MarchApril and July-August 2011. Habitats: SSHU= sparse shrubby; DSHU= dense shrubby; $\mathrm{SARB}=$ sparse arboreal; $\mathrm{DARB}=$ dense arboreal; $\mathrm{SSHAR}=$ sparse shrubby-arboreal and DSHAR= dense shrubby-arboreal.

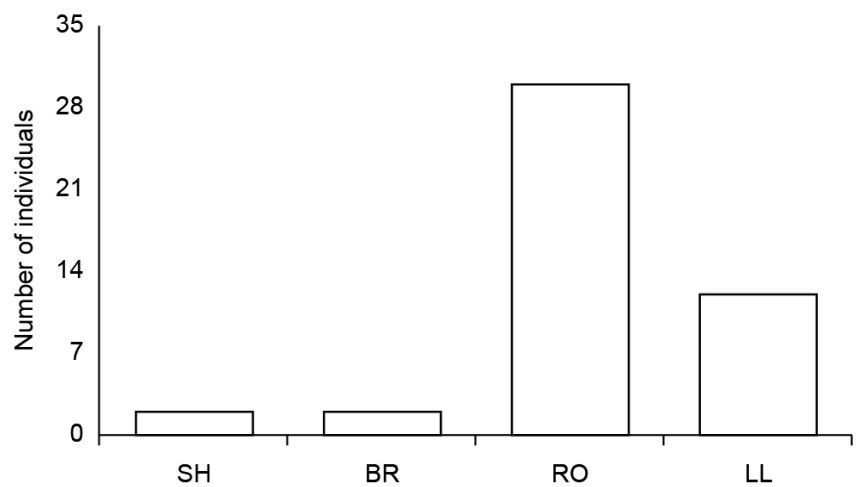

Figure 3. Number of individuals of Anotosaura vanzolinia by microhabitats at Complexo Aluízio Campos, Campina Grande, Paraíba State, Brazil, in March-April and July-August 2011. Microhabitats: $\mathrm{SH}=$ leaf litter around shrubs; $\mathrm{BR}=$ leaf litter among bromeliads; $\mathrm{RO}=$ leaf litter around rocky outcrops and $\mathrm{LL}=$ leaf litter isolated.
The diet of A. vanzolinia showed differences between body size groups. For individuals with a $\mathrm{SVL}<30 \mathrm{~mm}$, the predominant food item was Hymenoptera-Formicidae $(\mathrm{F} 0 \%=62.50, \mathrm{~N} \%=70.83$, $\mathrm{V} \%=57.58)$, followed by Araneae $(\mathrm{FO} \%=25, \mathrm{~N} \%=8.33$, $\mathrm{V} \%=12.12)$. The IRI showed higher values for HymenopteraFormicidae (87.46\%) (Table 2). However, for individuals with a SVL $>30 \mathrm{~mm}$, the most frequent food item was Isoptera $(50 \%)$, followed by Hymenoptera-Formicidae (40\%) and eggs of invertebrates $(26.67 \%)$. The highest values of numerical abundance were recorded for eggs of invertebrates (35.32\%), followed by Isoptera $(30.86 \%)$ and Hymenoptera-Formicidae (14.87\%) (Table 2). Volumetrically, Isoptera (30.33\%), eggs of invertebrates (17.45\%) and HymenopteraFormicidae (15.93\%) again were predominant. The IRI for the group with $\mathrm{SVL}>30 \mathrm{~mm}$ showed higher values for the order Isoptera $(47.43 \%)$, followed by eggs of invertebrates $(21.81 \%)$ and Hymenoptera-Formicidae (19.10\%) (Table 2). The amplitude of the niche calculated for this species resulted in a value of $H^{\prime}=7.21$. Individuals with a SVL $<30 \mathrm{~mm}$ showed a niche amplitude of $\mathrm{H}^{\prime}=0.78$, whereas that of individuals with a SVL $>30 \mathrm{~mm}$ was $H^{\prime}=6.43$.

\section{Discussion}

The vegetation of the Complexo Aluízio Campos can be characterized as consisting of medium-sized shrubs with an open canopy and a large amount of leaf litter, which creates an important microenvironment for occupation by $A$. vanzolinia. Thus, in terms of microhabitat use, A. vazolinia is similar to other gymnophthalmids of the Amazon and Atlantic rainforest (Vitt et al. 2007, Maia et al. 2011). However, the results of this study show the use of other habitats by the species in the Caatinga, since the work of Delfim \& Freire (2007) for gymnophthalmid lizards recorded only arboreal dense vegetation or dense shrubby-arboreal vegetation as a habitat. The occupation of

Table 1. Frequency of Occurrence (FO\%), Numerical Percentage (N\%), Volumetric Percentage (V\%) and Index of Relative Importance (IRI) of food items recorded in the digestive tract of Anotosaura vanzolinia captured in Complexo Aluízio Campos, Campina Grande, Paraíba State $(* n i=$ unidentified).

\begin{tabular}{lrrrr}
\hline \multicolumn{1}{c}{ Prey type } & FO & FN & FV & \%IRI \\
\hline $\begin{array}{l}\text { MOLLUSCA } \\
\quad \text { Gastropoda }\end{array}$ & 2.63 & 0.34 & 1.06 & 0.06 \\
ARACNIDA & & & & \\
$\quad$ Aranae & 18.42 & 3.41 & 8.61 & 3.89 \\
MIRIAPODA & & & & \\
$\quad$ Diplopoda & 2.63 & 0.34 & 0.40 & 0.03 \\
CRUSTACEA & & & & \\
$\quad$ Isopoda & 5.26 & 0.68 & 0.93 & 0.15 \\
HEXAPODA & & & & \\
$\quad$ Isoptera & 39.47 & 28.33 & 29.01 & 39.77 \\
Coleoptera & 15.79 & 3.41 & 4.24 & 2.12 \\
$\quad$ Coleoptera (larvae) & 5.26 & 0.68 & 0.40 & 0.10 \\
$\quad$ Hymenoptera (Formicidae) & 44.74 & 19.45 & 17.75 & 29.24 \\
$\quad$ Diptera & 7.89 & 1.02 & 0.40 & 0.20 \\
$\quad$ Blattodea & 5.26 & 2.05 & 5.03 & 0.65 \\
$\quad$ Lepidoptera (larvae) & 2.63 & 0.68 & 7.42 & 0.37 \\
$\quad$ Insect eggs (ni) & 21.05 & 32.42 & 16.69 & 18.17 \\
$\quad$ Insect larvae (ni) & 21.05 & 6.48 & 7.28 & 5.09 \\
PLANT & & & & \\
$\quad$ Plant Material & 5.26 & 0.68 & 0.79 & 0.14 \\
\hline & & & &
\end{tabular}


Table 2. Frequency of Occurrence (FO\%), Numerical Percentage (N\%), Volumetric Percentage (V\%) and Index of Relative Importance (IRI) of food items recorded in the digestive tract of Anotosaura vanzolinia captured in Complexo Aluízio Campos, Campina Grande, Paraíba State. (SVL = snout-vent length).

\begin{tabular}{|c|c|c|c|c|c|c|c|c|}
\hline \multirow{2}{*}{ Prey type } & \multicolumn{4}{|c|}{ Individuals with $\mathrm{SVL}<30 \mathrm{~mm}(\mathrm{n}=10)$} & \multicolumn{4}{|c|}{ Individuals with SVL > 30 mm $(\mathrm{n}=33)$} \\
\hline & FO & $\mathbf{F N}$ & FV & \%IRI & FO & $\mathbf{F N}$ & FV & \%IRI \\
\hline \multicolumn{9}{|l|}{ MOLLUSCA } \\
\hline Gastropoda & - & - & - & - & 3.33 & 0.37 & 1.11 & 0.08 \\
\hline \multicolumn{9}{|l|}{ ARACNIDA } \\
\hline Aranae & 25.00 & 8.33 & 12.12 & 5.57 & 12.50 & 2.97 & 8.45 & 2.95 \\
\hline \multicolumn{9}{|l|}{ MIRIAPODA } \\
\hline Diplopoda & 12.50 & 4.17 & 9.09 & 1.81 & - & - & - & - \\
\hline \multicolumn{9}{|l|}{ CRUSTACEA } \\
\hline Isopoda & - & - & - & - & 6.67 & 0.74 & 0.97 & 0.18 \\
\hline \multicolumn{9}{|l|}{ HEXAPODA } \\
\hline Isoptera & - & - & - & - & 50.00 & 30.86 & 30.33 & 47.43 \\
\hline Coleoptera & 12.50 & 4.17 & 3.03 & 0.98 & 16.67 & 3.35 & 4.29 & 1.97 \\
\hline Coleoptera (larvae) & 12.50 & 4.17 & 6.06 & 1.39 & 3.33 & 0.37 & 0.14 & 0.03 \\
\hline Hymenoptera (Formicidae) & 62.50 & 70.83 & 57.58 & 87.46 & 40.00 & 14.87 & 15.93 & 19.10 \\
\hline Diptera & - & - & - & - & 10.00 & 1.12 & 0.42 & 0.24 \\
\hline Blattodea & - & - & - & - & 6.67 & 2.23 & 5.26 & 0.77 \\
\hline Lepidoptera (larva) & - & - & - & - & 3.33 & 0.74 & 7.76 & 0.44 \\
\hline Insect eggs (ni) & - & - & - & - & 26.67 & 35.32 & 17.45 & 21.81 \\
\hline Insect larvae (ni) & 12.50 & 8.33 & 12.12 & 2.79 & 23.33 & 6.32 & 7.06 & 4.84 \\
\hline \multicolumn{9}{|l|}{ PLANT } \\
\hline Plant Material & - & - & - & - & 6.67 & 0.74 & 0.83 & 0.16 \\
\hline
\end{tabular}

sites with shrubby vegetation is shared with other lizards of the family, such as Acratosaura mentalis (Amaral 1933) (Delfim \& Freire 2007).

The abundance of $A$. vanzolinia was greatest in the leaf litter around rocky outcrops, covered by hyper-xerophile vegetation. In another study in the Caatinga, the species was found only at the base of a rocky outcrop (Rodrigues 1986). However, Rodrigues (2003), characterized the species of the Caatinga as relictual, because $A$. vanzolinia demonstrated a preference for habitats with dense vegetation and a microenvironment of milder temperatures. Northeastern Brazil is composed of residual reliefs, which serves as evidence of present and former integration between the Atlantic forest and the Caatinga, as shown by Borges-Nojosa \& Caramaschi (2003). These authors highlight the importance of these ombrophile areas to the relictual fauna. The same species was also recorded in the Agrest (Vanzolini 1974) and Cariri microregion (Grizante 2009) in environmental with the same characteristics, corroborating with this study.

The substrate type was highly influential for the distribution of lizards. The preference for a substrate rich in organic matter facilitates the movement and burrowing habit as compared to a clayey or more compacted substrate. These data corroborate those of Freire (1996) and Delfim \& Freire (2007), where A. vanzolinia is characterized by a substrate with these characteristics, in contrast to other species of the same family, which were found on different substrates, such as Vanzosaura rubricauda (Boulenger, 1902), which inhabited sandy or clayey soil. The morphology is primarily correlated with its fossorial habit and consequently with the type of microhabitat that the species chooses to utilize, suggesting they use more of the physical properties among substrates (Grizante 2009). The evolution of the morphology and limb reduction has been suggested to be adaptive for fossorial locomotion by subterranean crawl or locomotion by ripples in environments with leaf litter (Grizante 2009, Roscito 2010, Barros et al. 2011).

The diet of A. vanzolinia was composed of 14 prey types, comprising mostly social or isolated arthropods. Anaya-Rojas et al. (2010) studied the diet of Ptychoglossus bicolor and observed 11 prey types in its diet, which was mainly composed of isopods. The high proportion of Isoptera in the diet of Anotosaura vanzolinia is indicative of opportunistic behavior, as there were a large number of nests of these organisms in the study area. Termites maintain trails connecting nests to food sources using pheromones, which are intercepted by active foragers that mainly use chemoreception to detect prey (Novaes-e-Silva \& Araújo 2008).

The body shape and fossorial habit of $A$. vanzolinia characterize it as an active forager, capturing a range of prey with low mobility or with social behavior, such as termites (Menezes et al. 2006). Predation on small social insects is generally considered advantageous for lizards because it represents a concentrated and plentiful food at a relatively low energy cost, since lizards with this type of foraging have a high level of physical activity and energy expenditure (Novaes-e-Silva \& Araújo 2008). Other prey are restricted in movement (insect larvae) or immobile (insect eggs), indicating the opportunism of the species. The conservation of food preferences in the Gymnophthalmidae might have permitted the extensive radiation of the family into fossorial microhabitats (Barros et al. 2011).

Furthermore, the species also fed on prey that had a greater mobility, such as beetles and spiders, as well as ants that also have social grouping. This behavior can also be considered opportunistic, due to the leaf litter environment used by the lizard, since active foragers invest in exploiting the availability of food items in their habitat (Novaes-e-Silva \& Araújo 2008).

The species showed a high niche amplitude $\left(\mathrm{H}^{\prime}=7.21\right)$ compared to other Gymnophthalmidae lizards such as Vanzosaura rubricauda 
(Boulenger, 1902) $\left(\mathrm{H}^{\prime}=0.95\right)$ and Micrablepharus maximiliani (Reinhardt \& Luetken 1862) $\left(\mathrm{H}^{\prime}=1.46\right)$ in the Brazilian Cerrado (Aquino 2010). These differences reflect the greater number of prey items in the diet of $A$. vanzolinia, characterizing it as a generalist species. Species of other families of active forager lizards such as the Anguidae Ophiodes fragilis Raddi 1820, have also been characterized as generalist species (Montechiaro 2008). Larger lizards have larger niche amplitude than smaller lizards and thus, Novaes-e-Silva \& Araújo (2008) suggested that active foragers establish a search circuit from a central point, which is used for sleeping and as the lizard grows, the search circuit increases, as well as the size of the prey eaten.

The ingestion of ants by lizards that forage actively is uncertain, although there are records of ant predation by other active lizard foragers, such as those of the Gymnophthalmidae family (Albuquerque 2010, Silva 2008). The orders Araneae and Coleoptera were also items identified as important in the diet of organisms in this study, although more frequently for smaller lizards. Albuquerque (2010) reported spiders as an important component of the diet of Arthrosaura reticulata (O'Shaughnessy, 1881) and Cercosaura ocellata (Wagler, 1830), which showed a high numeric and volumetric intake of prey. Silva (2008) showed a high rate of consumption of Coleoptera by Dryadosaura nordestina Rodrigues, Freire, Pellegrino \& Sites Jr., 2005 in an Atlantic Forest area in the Northeast Brazil. Food preferences appear to be relatively conserved throughout the phylogeny of the group, which might be one reason for the extensive radiation of gymnophthalmids into fossorial microhabitats (Barros et al. 2011).

Studies on the trophic ecology of lizards, especially concerning active foragers, have shown that species have specific diets (generalist or specialist), according to the environment they inhabit (Albuquerque 2010, Aquino 2010, Montechiaro 2008, Silva 2008), which contradicts previous suggestions that the diet of lizard species depends on their type of foraging ("sit-and-wait" or active foraging). From this perspective, the importance of further ecological studies on lizard species are necessary, as suggested by Rodrigues (2003), who indicated that certain species of lizards (including $A$. vanzolinia) are currently being looked at in a generalized manner due to the absence of more detailed studies.

\section{References}

ALBUQUERQUE, S. 2010. Composição faunística e ecologia dos lagartos da floresta do Baixo Rio Môa - Acre. Dissertação de Mestrado, Universidade Federal do Are, Rio Branco.

ALVES, L.S., ALBUQUERQUE, H.N., BARBOSA, J.S. \& AGUIAR, C.B. 2010. Ações Socioeducativas e ambientais no Complexo Aluízio Campos. Rev. Bras. Info. Cient. 1(1):13-21.

ANAYA-ROJAS, J.M., SERRANO-CARDOZO, V.H. \& RAMÍREZPINILLA, M.P. 2010. Diet, microhabitat use, and thermal preferences of Ptychoglossus bicolor (Squamata: Gymnophthalmidae) in an organic coffee shade plantation in Colombia. Pap. Avulsos Zool. 50(10):159-166.

AQUINO, D.C.P.S. 2010. Dieta e sobreposição de nicho trófico de duas espécies sintópicas de lagartos gimnoftalmídeos do Cerrado e do Pantanal do Mato Grosso do Sul, Brasil. Dissertação de mestrado, Universidade Federal de Mato Grosso do Sul, Campo Grande.

ARZABE, C., SKUK, G., SANTANA, G.G., DELFIM, F.R., LIMA, Y.C.C. \& ABRANTES, S.H.F. 2005. Herpetofauna da área de Curimataú, Paraíba. In Análise das variações da biodiversidade do bioma Caatinga: Suporte a estratégias regionais de conservação (F.S. Araújo, M.J.N. Rodal \& M.R.V. Barbosa, eds.) Brasília, 434p.

BARROS, F.C., HERREL, A. \& KOHLSDORF, T. 2011. Head shape evolution in Gymnophthalmidae: does habitatuse constrain the evolution of cranial design in fossorial lizards? J. Evol. Biol. 24:2423-2433. http://dx.doi. $\operatorname{org} / 10.1111 / \mathrm{j} .1420-9101.2011 .02372 . x$
BORGES-NOJOSA, D. \& CARAMASCHI, U. 2003. Composição e análise comparativa da diversidade das afinidades biogeográficas dos lagartos e anfisbenídeos (Squamata) dos brejos nordestinos. In Ecologia e Conservação da Caatinga. (I.R. Leal, M. Tabarelli \& J.M.C. Silva, eds.) Editora Universitária da UFPE, Recife, p.463-512.

CAPPELLARI, L.H., LEMA, T., PRATES JUNIOR, P. \& ROCHA, C.F.D. 2007. Diet of Teius oculatus (Sauria, Teiidae) in southern Brazil (Dom Feliciano, Rio Grande do Sul). Iheringia, Sér. Zool. 97(1):31-35.

DELFIM, F.R. \& FREIRE, E.M.X. 2007. Os lagartos gimnoftalmídeos (Squamata: Gymnophthalmidae) do Cariri Paraibano e do Seridó do Rio Grande do Norte, Nordeste do Brasil: Considerações acerca da distribuição geográfica e ecologia. Oecol. Bras. 11(3):365-382. http:// dx.doi.org/10.4257/oeco.2007.1103.07

DIAS, E.J.R. \& ROCHA, C.F.D. 2007. Niche differences between two sympatric whiptail lizards (Cnemidophorus abaetensis and C. ocellifer, Teiidae) in the restinga habitat of northeastern Brazil. Braz. J. Biol 67(1):41-46. http://dx.doi.org/10.1590/S1519-69842007000100006

FREIRE, E.M.X. 1996. Estudo ecológico e zoogeográfico sobre a fauna de lagartos (Sauria) das Dunas de Natal, Rio Grande do Norte e da Restinga de Ponta de Campina, Cabedelo, Paraíba, Brasil. Rev. Bras. Zool. 13(4):903-921. http://dx.doi.org/10.1590/S0101-81751996000400012

GOGLIATH, M., RIBEIRO, L.B. \& FREIRE, E.M.X. 2010. Geographic distribution. Anotosaura vanzolinia (NCN). Brazil: Rio Grande do Norte. Herpetol. Rev. 41: 243-243.

GRIZANTE, M.B. 2009. Relações evolutivas entre ecologia e morfologia serpentiforme de lagartos microteiídeos (Sauria: Gymnophthalmidae). Dissertação de mestrado, Faculdade de Filosofia, Ciências e Letras, Universidade de São Paulo, Ribeirão Preto.

KOLODIUK, M.F. 2008. Dieta e comportamento de forrageio de duas espécies de Tropidurus (Squamata, Tropiduridade) em uma área de Caatinga do Nordeste do Brasil. Dissertação de mestrado, Universidade Federal do Rio Grande do Norte, Natal.

KUNZ, T.S., GHIZONI-JR, I.V. \& GRAIPE, M.E. 2011. Reptilia, Squamata, Gymnophthalmidae, Ecpleopus gaudichaudi Duméril and Bibron, 1839: Distribution extension in the state of Santa Catarina, Brazil. Check List. 7:11-12.

KREBS, C. J. 1989. Ecological Methodology. Harper and Row Publishers, New York, 654p.

LIOU, N.S. 2008. História natural de duas espécies simpátricas de Enyalius (Squamata, Leiosauridae) na Mata Atlântica do sudeste brasileiro. Dissertação de mestrado, Instituto de Biociências, Universidade de São Paulo, São Paulo.

MAIA, T., ALMEIDA-GOMES, M., SIQUEIRA, C.C., VRCIBRADIC, D., KIEFER, M.C. \& ROCHA, C.F.D. 2011. Diet of the lizard Ecpleopus gaudichaudii (Gymnophthalmidae) in Atlantic Rainforest, state of Rio de Janeiro, Brazil. Zoologia. 28(5):587-592. http://dx.doi.org/10.1590/ S1984-46702011000500006

MENEZES, V.A., AMARAL, V.C., SLUYS, M.V. \& ROCHA, C.F.D. 2006. Diet and foraging of the endemic lizard Cnemidophorus littoralis (Squamata, Teiidae) in the Restinga de Jurubatiba, Macaé, RJ. Rev. Bras. Biol. 66(3):803-807.

MONTECHIARO, L. 2008. Biologia de Ophiodes fragilis (Squamata: Anguidae):dieta e reprodução, no Sul do Brasil. Dissertação de mestrado, Universidade Federal de Santa Maria, Santa Maria.

NOVAES-E-SILVA V. \& ARAÚJO, A.F.B. 2008. Ecologia dos lagartos brasileiros. Ed. Technical Books, Rio de Janeiro, 256p.

PELEGRINO, K.C.M., RODRIGUES, M.T., YONENAGA-YASSUDA, Y. \& SITES, J.W. 2001. A molecular perspective on the evolution of microteiid lizards (Squamata, Gymnophthalmidae), and a new classification for the family. Biol. J. Linn. Soc. 74:315-338.

PINKAS, L., OLIPHONT, M.S. \& IVERSON, I.L.K. 1971. Food habits of albacore, bluefin tuna and bonito in California waters. Fish Bull. 152:1-105. 
ROCHA, C.F.D. 1994. Introdução à ecologia de lagartos brasileiros. In Herpetologia no Brasil, 1. (L.B. Nascimento, A.T. Bernardes \& G.A. Cotta, eds.). PUC-MG, Fundação Biodiversitas, Fundação Ezequiel Dias, Belo Horizonte.

ROCHA, H.L.S. Campina Grande: Dados geográficos. http://www.argonavis. com.br/helder/paraiba/campina/geografia.html (último acesso em 19/09/2011).

RODRIGUES, M.T. 1986. Uma nova espécie do gênero Phyllopezus de Cabaceiras: Paraíba: Brasil; com comentários sobre a fauna de lagartos da área (Sauria, Gekkonidae). Pap. Avulsos Zool. 36:237-250.

RODRIGUES, M.T. 2003. Herpetofauna da Caatinga. In Ecologia e Conservação da Caatinga. (I.R. Leal, M. Tabarelli \& J.M.C. Silva, eds.). Editora Universitária da UFPE, Recife, p.181-231.

ROSCITO, J.G. 2010. Desenvolvimento embrionário e a evolução da fossorialidade nos lagartos da tribo Gymnophthalmini (Squamata, Gymnophthalmidae). Tese de doutorado, Instituto de Biociências, Universidade de São Paulo, São Paulo.

SANTANA, D.O., FARIA, R.G., RIBEIRO, A.S., OLIVEIRA, A.C.F., SOUZA, B.B., OLIVEIRA, D.G., SANTOS, E.D.S., SOARES, F.A.M., GONÇALVES, F.B., CALASANS, H.C.M., VIEIRA, H.S., CAVALCANTE, J.G., MARTEIS, L.S., ASCHOFF, L.C., RODRIGUES, L.C., XAVIER, M.C.T., SANTANA, M.M., SOARES, N.M., FIGUEIREDO, P.M.F.G., BARRETTO, S.S.B., FRANCO, S.C. \& ROCHA, S.M. 2011. Utilização do microhábitat e comportamento de duas espécies de lagartos do gênero Tropidurus numa área de Caatinga no Monumento Natural Grota do Angico. Scientia Plena. 7(4):1-9.
SILVA, U.G. 2008. Diversidade de espécies e ecologia da comunidade de lagartos de um fragmento de Mata Atlântica no Nordeste do Brasil. Dissertação de Mestrado, Centro de Biociências, Universidade Federal do Rio Grande do Norte, Natal.

TEIXEIRA-FILHO, P.F., ROCHA, C.F.D \& RIBAS, S.C. 1995. Aspectos da ecologia termal e uso do habitat por Cnemidophorus ocellifer (Sauria: Teiidae) na Restinga da Barra de Maricá, RJ. Oecol. Bras. 1:155-165

VANZOLINI, P.E. 1974. Ecological and geographical distribution of lizards in Pernambuco, Northeastern Brasil (Sauria). Pap. Avulsos Zool. 18(4):61-69.

VARGENS, M.M.F., DIAS, E.J.R. \& LIRA-DA-SILVA, R.M. 2008. Ecologia térmica, período de atividade e uso de microhabitat do lagarto Tropidurus hygomi (Tropiduridae) na restinga de Abaeté, Salvador, Bahia, Brasil. Bol. Mus. Biol. Mello Leitao. 23:143-156.

VITT, L.J., PIANKA, E.R., COOPER-JUNIOR, W.E. \& SCHWENK, K. 2003. History and the global ecology of Squamate Reptiles. Am. Nat. 162(1):44-61. http://dx.doi.org/10.1086/375172

VITT, L.J., AVILA-PIRES, T.C.S., ESPOSITO, M.C., SARTORIUS, S.S. \& ZANI, P.A. 2007. Ecology of Alopoglossus angulatus and A. atriventris (Squamata, Gymnophthalmidae) in western Amazonia. Phylomedusa. 6:11-21.

VITT, L.J., MAGNUSSON, W.E., AVILA-PIRES, T.C.S. \& LIMA, A.P. 2008. Guia de Lagartos da Reserva Adolpho Ducke, Amazônia Central. Ed. Attema, Manaus, 176p.

ZAR, J.H. 1996. Biostatistical Analysis. 3rd ED. Prentice May. Englewoods Cliffs, 662p. 